\section{Improving transfusion practice in transfusion dependent thalassaemia patients}

\author{
Chathupa Wickremaarachchi,, 1,2 \\ Elizabeth McGill, ${ }^{1}$ Annmarie Bosco, ${ }^{1,2}$ \\ Giselle Kidson-Gerber ${ }^{1,2}$ \\ 'Department of Haematology, Prince of \\ Wales Hospital, Sydney; ${ }^{2}$ Prince of \\ Wales Clinical School, University of New \\ South Wales, Sydney, NSW, Australia
}

\begin{abstract}
The aim of this study was to improve current transfusion practice in transfusiondependent thalassaemia patients by determining whether safe transition from triplewashed red cells (TWRC) to leucodepleted red cells (LDRC), increasing transfusion rates, reducing the use of frusemide and creating uniform practice across patients is possible. In patients receiving regular transfusions (50), triple-washed red blood cells were changed to LDRC, transfusion rates were increased to $5 \mathrm{~mL} / \mathrm{kg} / \mathrm{h}$ (in line with the Cooley's Foundation guidelines) to a maximum of $300 \mathrm{~mL} / \mathrm{h}$ and frusemide was ceased. Medical review occurred at completion of the transfusion. Of the 20 patients on TWRC, 18 were transitioned to leucodepleted red cells (90\%). Recurrent allergic reactions in 2 patients required re-institution of TWRC. 7 of the 8 patients on regular frusemide ceased this practice with no documented transfusion-related fluid overload. One patient refused. Of the eligible 50 patients, 20 patients $(40 \%)$ were increased to the maximum transfusion rate of 300 $\mathrm{mLs} / \mathrm{h} ; 6$ (12\%) increased rate but refused to go to the maximum; $9(18 \%)$ refused a change in practice and $15(30 \%)$ were already at the maximum rate. There was only one documented transfusion reaction (palpitations) however this patient was able to tolerate a higher transfusion rate on subsequent transfusions. Thalassemia patients on TWRC were safely transitioned to LDRC. Transfusion rates were safely increased, with a calculated reduction in day-stay bed time of $17.45 \mathrm{~h}$ per month. This confirms a guideline of $5 \mathrm{~mL} / \mathrm{kg} / \mathrm{h}$ for transfusion-dependant thalassaemia patients with preserved cardiac function is well tolerated and may be translated to other centres worldwide.
\end{abstract}

\section{Introduction}

Thalassaemia is an autosomal recessive inherited haemoglobinopathy, which results in abnormal haemoglobin formation. Those with severe genetic defects are transfusiondependent either from early childhood (thalassaemia major) or later in life (thalassaemia intermedia). Two to four units of packed red blood cells are usually transfused every 3 to 4 weeks. Previously, in the attempt to reduce the potential for alloimmunisation, thalassemia patients may have received triple-washed red cells. In November 2008, the national blood service introduced universal leucodepletion of red cells in addition to change in manufacturing to reduce the plasma volume to $<10 \mathrm{~mL} /$ red cell bag - changes which potentially mitigated the need for TWRC.

Attendance at transfusion, including travel to the centre, is a significant time requirement, and so as we optimise the medical management, we also aim to optimise our patients' capacity to function in everyday life without compromise to safety. The biggest modifiable factor in this time requirement is the rate at which blood products are transfused.

Although the American-based Cooley's Anaemia Foundation recommends transfusing patients with preserved cardiac function at a rate of $5 \mathrm{~mL} / \mathrm{kg} / \mathrm{h},{ }^{1}$ the most recent international thalassaemia guidelines are less clear, stating transfusion of 2-3 units should take approximately 3-4 h. ${ }^{2}$

Correspondence with other thalassaemia centres in both the United Kingdom and Australia showed a wide variation in practice (Greely C, Transfusion practices at Monash Health, Victoria, 2015; and Prescot E, Transfusion practices at Whittington Hospital, UK, 2015; personal correspondence).

\section{Aim}

To improve current transfusion practice in transfusion-dependent thalassaemia patients at a tertiary haemoglobinopathy centre, by determining whether transition off TWRC, increasing transfusion rates, reducing the use of frusemide and creating uniform practice across patients is possible.

\section{Materials and Methods}

A review was undertaken of all 54 haemoglobinopathypatients (all but one,
Correspondence: Chathupa Wickremaarachchi, Prince of Wales Hospital, Randwick, NSW, 2031, Australia.

E-mail: chathuw@hotmail.com

Key words: Thalassemia; transfusion medicine.

Acknowledgments: the authors would like to thank the patients, volunteers, and colleagues at the hospital and laboratory for their support and assistance, in particular Kristen Brown, Gemma Carroll, Kirsten Scott and Phil Mondy.

Conflicts of interest: the authors do not have any conflicts of interest to disclose.

Received for publication: 28 May 2017.

Revision received: 29 August 2017.

Accepted for publication: 4 September 2017.

This work is licensed under a Creative Commons Attribution 4.0 License (by-nc 4.0).

(c) Copyright C. Wickremaarachchi et al., 2017 Licensee PAGEPress, Italy

Thalassemia Reports 2017; 7:6821

doi:10.4081/thal.2017.6821

who is a transfusion dependent sickle cell anaemia patient, had thalassaemia) in our unit who received regular transfusions. The following factors were reviewed: i) blood products used; ii) weight-based transfusion rates; iii) post-transfusion use of frusemide; iv) presence of cardiac impairment (based on LV function and T2* cardiac MRI score) and transfusion reactions.

Those patients with a history of cardiac impairment and transfusion reactions were excluded from the trial. The remaining patients $(n=50)$ underwent the following: $i)$ patients who were receiving triple-washed packed cells (TWPC) were transitioned to leucodepleted red blood cells (LDRC) over the year 2009; ii) cessation of frusemide use - this was carried out over a period of one month in 2015 to ensure all patients ceased use and to remove this confounder from any transfusion adverse effects in the future. Adverse events were recorded on the electronic medical record; iii) increasing each patient's transfusion rate of LDRC to 5 $\mathrm{mL} / \mathrm{kg} / \mathrm{h}$ up to a maximum of $300 \mathrm{~mL} / \mathrm{h}$ over the following year 2015-2016; iv) each patient received a medical review at completion of transfusion to ensure the increased rate was tolerated. Adverse reactions were to be documented in the electronic medical record. 
Approval was granted from the Human Research Ethics Committee.

\section{Results}

The cohort of 54 patients had an average age of 37.4 years (range: 18-50), with a median transfusion rate of $3.86 \mathrm{~mL} / \mathrm{kg} / \mathrm{h}$, IQR [3.19, 4.35].

Eighteen $(90 \%)$ of the 20 patients receiving TWRC were successfully transitioned to LDRC. Recurrent allergic reactions in 2 patients required re-institution of TWRC. Overall there was no change in transfusion frequency or units received per transfusion episode after the intervention. The mean $\mathrm{Hb}$ of the patient group on TWRC was $100.93 \mathrm{~g} / \mathrm{L}$, and the mean $\mathrm{Hb}$ of the patient group on LDRC was $98.63 \mathrm{~g} / \mathrm{L}$. Using a Student's $t$-test, there was no signifmeans $(\mathrm{P}=0.07,95 \% \mathrm{CI})$.

Four patients were excluded from the frusemide and rate change due to documented cardiac impairment or previous transfusion reactions. 8 patients $(16 \%)$ were on regular post-transfusion frusemide. This practice was ceased in 7 after medical review with no documented transfusion-

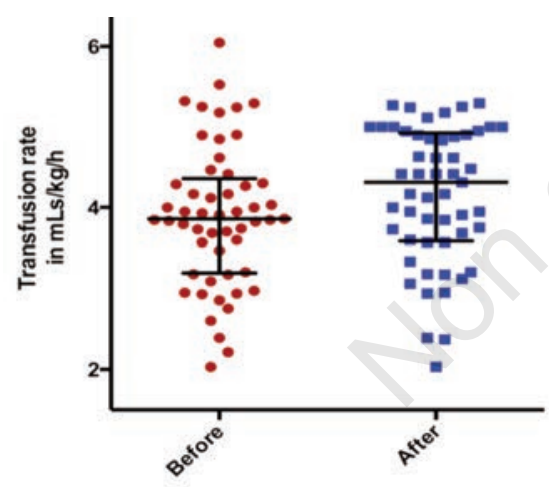

Figure 1. Comparison of transfusion rates before and after implementation of a uniform guideline icant difference found between the two

related fluid overload; one patient refused.

Transfusion rate optimisation in the eligible patients is summarised in Table 1 . Following implementation of the uniform guideline the median transfusion rate was higher at $4.31 \mathrm{~mL} / \mathrm{kg} / \mathrm{h}, \mathrm{IQR}[3.59,4.92]$ (Figure 1).

During the process there was one documented transfusion reaction (palpitations) however this patient was still able to tolerate a higher transfusion rate on subsequent transfusions (increase from 140 to 150 $\mathrm{mL} / \mathrm{h}$ ). Overall the patient population was receptive to the change in practice (Table 1), however maximum rates were unable to be achieved in $30 \%$.

\section{Discussion}

In the first stage of this substantial change in transfusion practice, we were able to transition $90 \%$ of patients off TWRC to LDRC, which led to cost and time savings both at our hospital and at our state blood service levels, without a compromise in safety. An additional benefit included a reduction in the administration of pre-transfusion hydrocortisone in this high osteoporosis risk group. We were unable to demonstrate a greater volume in red cells, as theoretically there is loss of red cells during TWRC manufacturing.

The Cooley's Anaemia Foundation guideline of a transfusion rate of $5 \mathrm{~mL} / \mathrm{kg} / \mathrm{h}$ is well tolerated in this Australian population of thalassaemia patients without impaired cardiac function. None of these patients were on post transfusion frusemide to confound this result.

These patients are transfused on a regular basis and usually on weekends to accommodate work and family commitments. Increasing transfusion rates with subsequent reduction in the time spent in the outpatient centre is a significant improvement in the quality of their treatment. Assuming an average volume of 260 $\mathrm{mL}$ per unit of blood $(279 \mathrm{~mL}$ for triple washed units) $1047 \mathrm{~min}$ were saved over a 4 week period, equating to nearly $17.5 \mathrm{~h}$ of

Table 1. Outcome of change to a uniform transfusion practice.

\begin{tabular}{lcc} 
Outcome of rate change & N & Proportion \\
No rate change, already at maximum & 15 & $30 \%$ \\
Rate increased to $5 \mathrm{~mL} / \mathrm{kg} / \mathrm{h}$ with a maxmium of $300 \mathrm{~mL} / \mathrm{h}$ & 20 & $40 \%$ \\
\hline Increased rate but refused to go to maximum rate & 6 & $12 \%$ \\
Refused change in practice & 9 & $18 \%$ \\
\hline
\end{tabular}

reduced treatment time. As our unit also administers outpatient chemotherapy this increased efficiency helps the entire unit provide a better service.

This change in practice may be adopted by other haemoglobinopathy units, with careful selection of age-appropriate patients with preserved cardiac function and facilities for prompt medical review. The benefits for the patients are predominantly measured as reduced time within the healthcare facility, which may translate to improved patient satisfaction and quality of life. However, this was not measured objectively in our study.

Furthermore, refusal of a change in practice occurred in $30 \%$, which was unexpected given our intention to maximise quality of life. This highlights the challenge and complexities of introducing a change in practice in the management of chronic disease. The literature on managing patients with chronic disease has not yet explored whether this aversion to practice modification is widespread in similar patient populations and requires further research.

These findings are applicable to other units, cognisant that it is a single centre study, using leucodepleted packed cells in a high resource setting.

\section{Conclusions}

We confirm that a transfusion rate of 5 $\mathrm{mL} / \mathrm{kg} / \mathrm{h}$ of leucodepleted red cells for transfusion-dependent thalassaemia patients with preserved cardiac function is well tolerated and could be translated to other centres worldwide. Changing our practice resulted in a calculated reduction in daystay chair time of $17.45 \mathrm{~h}$ per month. However in patients with chronic illness, change can be difficult and not all patients consented to a change in transfusion practice.

\section{References}

1. Vichinsky E, Levine L. Standards of care guidelines for thalassemia. Oakland, CA: Children's Hospital \& Research Center Oakland; 2012. Available from: http://thalassemia.com/ documents/SOCGuidelines2012.pdf Accessed: 20/10/2016.

2. Capellini MD, Cohen A, Porter J, et al. Guidelines for the management of transfusion dependent thalassaemia (TDT), $3^{\text {rd }}$ ed. Nicosia, Cyprus: Thalassaemia International Foundation; 2014. 